\title{
Utterance-final particles in Klang Valley Malay
}

\author{
TOM G. HOOGERVORST
}

\begin{abstract}
This paper examines a group of small morphemes analysed as "utterance-final particles" in the Malay variety of the Klang Valley, West Malaysia. It provides a preliminary investigation into their usage and diachronic evolution, connecting fieldwork-based findings with extant research on other Malay varieties. There is no univocal definition of utterance-final particles - known by other scholars as "discourse particles" or "pragmatic particles" - nor broad agreement on the term's conceptual validity. Most previous research on Malay varieties approaches these units as unbound morphemes with no grammatical and little obvious lexical meaning, relegating their functionality to the realm of pragmatics. This study calls attention to data from Klang Valley Malay to demonstrate that particles cannot easily be divided into "grammatical" and "pragmatic" categories. Most utterance-final particles discussed here are etymologically derived from verbs, adverbs, interjections and other word classes and can at best be classified as "part-time" pragmatic particles. They display varying levels of grammaticality and pragmaticality depending on their intonation and syntactic position.

KEYWORDS

Utterance-final particles; Klang Valley Malay; grammaticalization; colloquial Malay; pragmaticalization.
\end{abstract}

\section{INTRODUCTION}

From the outset, it should be clarified that no scholarly consensus exists on what "utterance-final particles" are, nor what "Klang Valley Malay" might be. I therefore stress that both labels are used for the sake of convenience. Utterance-final particles (henceforth UFPs) - also known as "pragmatic particles" or "discourse particles" - are remarkably heterogenous and

TOM G. HOOGERVORST is a researcher at the Royal Netherlands Institute of Southeast Asian and Caribbean Studies (KITLV). His research interests include historical linguistics, language contact, and youth language, with a focus on Indonesia and Malaysia. He is currently finishing a book on the language history of Indonesia's Chinese minority. He has also published on Sino-Malay books and newspapers and their historical value to understand the vibrant urban society of late-colonial Indonesia from a non-European perspective. Tom Hoogervorst may be contacted at: hoogervorst@kitlv.nl.

(C) 2018 Faculty of Humanities, Universitas Indonesia

TOM G. HOOGERVORST | DOI: 10.17510/wacana.v19i2.704. 
language-specific linguistic items, as we are reassured by almost all overview articles on this hypothetical word class. According to one early definition, they are "short words, often monosyllabic, that add a frame of reference (temporal, attitudinal, et cetera) to a phrase or clause" (Zorc 1977: 157). A more recent publication asserts that "they are simply non-inflecting parts of speech" (Bayer and Struckmayer 2017: 1). Yet these and other definitions are by no means univocally accepted, as is discussed in more detail in the first section of this paper.

My usage of the shorthand "Klang Valley Malay" (henceforth KVM) reflects little more than the fact that I have collected the data for this article in Kuala Lumpur and its surrounding suburbs. To my knowledge, there is little evidence to consider the Malay of the Klang Valley as significantly distinct from the varieties of the southern Malay Peninsula more broadly, and so I do not claim that the evidence discussed here represents a distinct regional dialect. Nevertheless, I hold it likely that data from Singapore, Riau, the north of Malaysia, or other geographically contiguous regions would have yielded a partly different analysis. For this reason I have opted not to use a "broader" term, such as West Malaysian Malay. More sociolinguistic and typological context of the type of Malay examined here is provided in the second section.

UFPs have been studied in the following Malay varieties: West Malaysian Malay (Koh 1990: 77-86; Goddard 1994, 2001), Sabah Malay (Hoogervorst 2011: 68-73), Manado Malay (Stoel 2005), Jakartan Indonesian (Ikranagara 1975; Sneddon 2006), and Indonesian (Wouk 1998, 1999, 2001; Sari 2008, 2011). UFPs in the English of Malaysia and Singapore have been examined by Platt and Mian (1989), Gupta $(1992,2006)$, and Li et al. (2016). As is the case cross-linguistically, most UFPs highlighted in these studies are monosyllabic unbound morphemes that exhibit distinct intonational patterns. Their polysemy is relatively well-understood and different functions have been identified for different syntactic positions and/or intonational patterns. Most studies have focused on the pragmatic aspects of these particles, yet - as will be demonstrated in this article - they must also be analysed as partly grammatical in nature. Some UFPs display near equivalents in English or other languages, yet they nevertheless require a description that takes into account both their propositional and discourse functions. Rather than focusing on one particle in particular, this study aims to offer a necessarily incomplete outline of UFPs in KVM, suggesting some directions for future research. It discusses both UFPs generally classified as such in the broader literature on Malay varieties (third section) and "non-canonical" UFPs displaying a range of different functions depending on their intonation and syntactic position (fourth section). Particularly in the utterance-final position, it is shown that the latter exhibit pragmatic functions akin to those found in "established" UFPs.

I am profoundly indebted to Don van Minde for directing my attention to Malay UFPs as early as 2007, when he organized an MA course on this topic at Leiden University, and for commenting on my paper soon afterwards. The present article is a thorough revision, taking into consideration more 
recent publications on UFPs. I owe another debt of gratitude to David Gil, for his comments during the Thirteenth International Symposium on Malay/ Indonesian Linguistics (6-7 June 2009, Senggigi) and especially for his valuable discussions more recently. I collected most data during fieldwork in Kuala Lumpur and its surrounding suburbs in April 2007 and February 2008. In the absence of digitalized, annotated and publicly accessible recordings, I cannot claim to present anything but a preliminary overview of UFPs in this variety of Malay. The topic is nevertheless hoped to spark further interest and scholarship within the field of Malay linguistics and beyond.

\section{Pragmatic PARTICLES AND THEIR PROBLEMS}

In view of the innumerable pages, monographs, and edited volumes spent on the definition and characteristics of utterance-final particles, pragmatic particles, discourse particles, and other near-synonyms, a relatively brief summary best serves the purposes of this article. Textbook examples of such words in English include actually, you know, so, well, and okay. In most discursive contexts, these units bear little obvious lexical meaning. Their function is chiefly pragmatic; they convey a speaker's attitude or emotion towards what is being said, or express a degree of intimacy or shared knowledge between speech participants. As such, the particles govern interpersonal understanding and intersubjective meaning. On a syntactical level, they are said to be noncompulsory to their "host clause". At the same time, they cannot occur in isolation. In other words, these particles are often claimed - not without controversy - to lay outside the information structure of the utterance to which they are attached, and can be omitted without affecting its grammaticality or propositional content ("truth-value").

Such particles frequently occur in informal communication. They often undergo phonological attrition (Lehmann 1985; Traugott 1988; Van Bogaert and Colleman 2013). It is not without difficulties to represent them accurately in writing, as their intonation is crucial to understand their pragmatic features of usage. Nevertheless, the ubiquity of such particles in informal online communication attests to the fact that native speakers face little difficulty in correctly interpreting their meaning in context (Li et al. 2016). Linguists, on the other hand, have a harder job in doing so; "In many grammars these aspects do not receive much attention, because in the study of discourse particles and focus marking, informants' intuitions and judgements are not very useful. In addition to an intimate knowledge of the language and a substantial corpus of spontaneous dialogues, advanced phonetic research is required as well" (Van Minde 2008: 555). Unsurprisingly, their correct use is intuitive and therefore a source of difficulty for second-language learners, as these particles rarely exhibit one-to-one correspondences in other languages.

There is little scholarly agreement on the precise typological features of these particles and the extent to which they form a distinct word class. ${ }^{1}$

1 For a broader discussion, see Östman (1981), Schiffrin (1987, 2003), Fraser (1990), Abraham (1991), Foolen (1996), Jucker and Ziv (1998), Blakemore (2002), Fischer (2006), Aijmer and 
Even the terminology - with competing and (semi-)overlapping terms such as discourse particles, pragmatic particles, discourse markers, modal particles, final particles, attitudinal particles, illocutionary particles, utterance particles, sentence-final particles, discourse connectives, pragmatic markers, interactional particles, interactive particles, lexical particles, and many others - illustrates how incongruous the wider literature on this topic has become. The most common Malay term is kata penegas ('emphatic words'). In the context of Malay varieties, the term UFP "works" because they are indeed utterance-final unbound morphemes, although - as will be shown in this article - a number of UFPs display semantically related homophones in other syntactic positions. ${ }^{2}$ That is to say, at least in the context of KVM, there is often no clear-cut distinction between UFPs and other word classes such as demonstratives and interjections.

\section{The MALAY EXAMINED IN THIS STUDY}

The Malay data analysed in this article have been collected in natural speech in Kuala Lumpur and its adjoining cities in the Klang Valley, West Malaysia. There is nevertheless little a priori evidence to support that KVM constitutes a separate Malay dialect. In fact, some of the examples presented here might also be considered grammatical in geographically contiguous varieties. Aside from regional differences, which in West Malaysia appear to be chiefly phonological and lexical (Asmah 2008), stylistic variety must also be taken into account. In the Malay imaginary, the three main sociolinguistic styles are, in the order of prestige: formal language (bahasa baku), colloquial language (bahasa basahan), and "Bazaar Malay" or foreigner talk (bahasa pasar). This article is chiefly concerned with the second category. Unlike bahasa pasar, which is associated with Chinese and Indian speakers (Aye 2005), bahasa basahan is regarded as the in-group vernacular of ethnic Malays (Koh 1990).

Previous scholars have asserted that Malaysia's authorities as well as the Malay speech community itself tend to discourage outsiders from speaking or studying colloquial Malay, instead typically resorting to the more stuffy formal language if not a form of foreigner talk (Coope 1953: 118-119; Goddard 1994: 146). Until relatively recent times, written representations of colloquial Malay were chiefly confined to popular magazines and comics produced by non-conformist Malay authors (Koh 1990: 12). This situation has gradually changed, especially in today's digital age; examples of colloquial Malay can easily be found on Youtube and various social media platforms. Recent fieldwork-based studies on this variety include Shoho (2006, 2013), Nomoto (2006a, 2006b), Soh $(2011,2015)$, and Nomoto and Wahab (2012). I assume more scholarship on this topic has been produced at Malaysian universities

Simon-Vandenbergen (2006), Maschler and Schiffrin (2015), Degand and Evers-Vermeul (2015), Crible (2017), Fedriani and Sansò (2017), Bayer and Struckmayer (2017).

2 It should also be recalled that grammaticalization by definition leads to decategorialization (Diewald 2011). For example, phrasal idioms can overlap with UFPs, as with African-American Vernacular English aight (< all right!) and knowmsayin (< do you know what I'm saying?). 
in the form of theses, yet such works have not been made broadly accessible. Compared to formal Malay, the colloquial varieties of Malay exhibit extensive use of UFPs, infrequent use of derivational morphology, and widespread borrowing from and code-mixing with English (Koh 1990: 35-8).

Given the fact that Kuala Lumpur is situated in the wider Selangor area, it has been inferred that the city's Malay variety was initially identical to the Selangor dialect. After decades of migration from across Malaysia and beyond, however, its Malay became less monodialectical (Asmah 1992: 29). The oft-assumed existence of a distinct Selangor Malay is itself problematic, as it is unclear how it differs from neighbouring varieties (Collins 1989: 239); more comparative research is needed on the (tentative) Malay dialects of Selangor, Melaka, Johor, Perak, Pahang, Singapore, and Riau. Most southern Peninsular varieties have in common their realization of the historical and orthographic $<\mathrm{u}>$ in word-final closed syllables as $/ \mathrm{o} /$, the $<\mathrm{i}>$ in word-final closed syllables as /e/, the $<\mathrm{r}\rangle$ as $/ \gamma /$ in the syllable onset and as zero $/ \varnothing /$ in the coda, and the word-final $<\mathrm{a}>$ as $/ \gamma /$ (except when the latter results from word-final r-elision). On a subdialectal level, some additional phonological features have been described by Asmah (2008). I have furthermore noticed that some speakers in Kuala Lumpur and its suburbs occasionally realize the word-final / $\mathrm{t}$ / as a glottal stop / $/$ / and the word-final / $/$ / as a glottal fricative $/ \mathrm{h} / .^{3}$ The latter features possibly reflect dialect features from other areas of Malaysia, as KVM has become relatively heterogenous due to migration to the metropole. Notwithstanding this phonological heterogeneity, I have chosen to represent this study's data in a relatively orthographic way, following the way this is often - but not always - done by native speakers.

Another typological feature of colloquial (West Malaysian) Malay of direct relevance to this study is the optional shortening of a number of frequently used words, typically by only retaining their final syllable. This process can affect a broad range of lexical items, yielding several monosyllabic UFPs and other unbound morphemes. ${ }^{4}$ According to Hussein (1973: 75), this reflects Thai influence, as it occurs most frequently in northern dialects. Of the particles discussed in this paper, ten have undergone evident phonological attrition: dah (< sudah), gak (< jugak), ja (< sahaja), jap (< sekejap), kan (< bukan), kot (< takut), lak (< pulak), ni (<ini), tah (< entah), and tu $(<i t u)$. As will be argued below, the monosyllabization of these particles is connected with their "pragmaticalization" (Diewald 2011; Degand and Evers-Vermeul 2015), that is, their acquisition and increase of pragmatic functions besides their grammatical functions.

\section{Canonical Malay UFPs}

This section highlights six KVM particles conventionally categorized as

3 The same has been documented in the Malay variety of Jugra, Selangor (Collins and Hassan 1988).

4 Lists of frequently monosyllabized words can be found in Koh (1990: 43-45) and Hoogervorst (2015: 29). 
UFPs (or pragmatic particles, discourse particles, and so forth), presented in alphabetical order. As most UFPs are polysemous, their usage is illustrated in multiple contexts, including declarative, interrogative, and imperative statements.

1. ah

The particle $a h$ is an emotive marker expressing the speaker's irritation or discomfort about the content of the utterance it follows. ${ }^{5}$ In KVM, its pragmatic nuances range from disapproval (1) to impatience (2) or disbelief (3) towards the utterance's propositional value.

1) Be-budak sekarang takda adab ah. RPD-kid now have.not courtesy PART

'Kids these days lack any courtesy!'

2) Aku send minggu depan ah!

1s send week next PART

'I'll send it next week already!'

3) Takkan ah dia suka kat kau. won't PART 3s like PREP 2s

'There's just no way she likes you.'

The same implication of discomfort is seen in imperative constructions (4-5) and rhetorical questions (6).

4) Jangan ah balik Johor! don't PART go.back Johor

‘Don't go back to Johor!'

5) Tolong ah jangan nak poyo sangat. please PART don't FUT arrogant very 'Please, don't be so arrogant.'

6) Kau sapa ah nak sound aku?

2s who PART FUT talk 1s

'Who are you to talk to me?'

The particle can also turn declarative statements into questions, indicating that the speaker expects an affirmative response. This usage furthermore expresses mild impatience (7-8).

5 This particle has also been described in West Malaysian Malay (Koh 1990: 75) and Jakartan Malay (Ikranagara 1975: 97-98). 
7) Boleh ah buat lagi?

can PART do again

'Can you do it again?'

8) Kau itu pun tak tau ah?

2s DEM even not know PART

'Don't you even know that?'

The UFP ah appears to go back to the homophonous interjection, which likewise expresses the speaker's discomfort or annoyance (9-10).

9) Ah, lelaki tu sama ja.

PART men PART same PART

'Ugh, men are all the same.'

10) Ah, korang ni ada-ada ja lah!

PART $2 p$ PART RDP-have PART PART

'Ugh, there's always something with you guys.'

2. ek

The particle $e k$ is used to attract the listener's attention. In declarative sentences, it expresses unpleasant surprise or annoyance at the propositional content of the utterance it follows (11-12).

11) Dia dah gemuk ek!

3s PART fat PART

'She's got fat!'

12) Sikit pun takleh ek.

a.bit PART cannot PART

'We can't even have a little.'

It functions as a solidarity marker in imperative constructions, conveying the speaker's hope that the listener will take the request or demand seriously (13-14).

13) Jangan puan marah ek.

Don't Ms. angry PART

'Don't be angry, Ms.' 
14) Plis tolong ek abang polis. please help PART older.brother police 'Please help us, officer'

In questions, ek encourages the listener to promptly answer what is being asked (15-16).

15) Nombor henpon kau berapa ek? number handphone $2 \mathrm{~s}$ how.much PART

'What's your mobile number?'

16) Cuti dah dekat, apa plen korang ek? holidays PART close what plan $2 \mathrm{p}$ PART

'The holidays are coming, what are your plans?'

It can also be used in rhetorical questions, in which case the particle carries assertive nuances (17-19)

17) Apa masalah kau ek?

what problem 2s PART

'What's your problem?'

18) Watpa minta maaf ek?

for.what ask forgiveness PART

'Why would I apologize?'

19) Camtu ek korang layan te-tamu?

like.that PART $2 \mathrm{p}$ serve RDP-guest

'Is that how you people treat your guests?'

\section{3. lah}

One of the best known and most versatile particles in colloquial Malay varieties - as well as Malaysian and Singaporean English - is lah, characterized by a broad range of meanings and relatively frequent usage. ${ }^{6}$ In general, lah - also written as $l a$ - places the focus on the word or phrase it follows. A range of pragmatic effects can result from this semantic core. Lah typically marks the speaker's emotional investment with the aim to inform the listener about something important or prevent a misunderstanding. It is often described as a solidarity marker that expresses sympathy, asserts agreement, and reduces social distance. However, an in-depth look at the often contradictory 
nuances lah reveals that it can equally well mark disapproval and emphasize the speaker's irritation, depending in part on the intonation (Goddard 1994).

The KVM data support the importance of context and suprasegmental features to interpret the function of lah. In examples (20-22), it conveys friendliness, light-heartedness or contentment. The propositions it modifies in these examples are of an assertive, affirmative or reassuring nature. In such cases, lah is lengthened and pronounced in a high-falling pitch.

20) Best lah tempat ni.

good PART place DEM

'This place is fantastic.'

21) Ya ja lah!

yes PART PART

'Of course!'

22) Gambar ini paling cun lah.

picture DEM most beautiful PART

'This picture is the most beautiful one.'

In examples (23-25), conversely, lah expresses irritation, impatience, or disapproval. It is not lengthened, contains a falling pitch, and it is followed by a short pause.

23) Dah, cepat lah pegi jumpa doktor!

PART fast PART go meet doctor

'Go and see a doctor fast!'

24) Cukup lah, aku tak nak tengok muka awak, faham? enough PART $1 \mathrm{~s}$ not want see face $2 \mathrm{~s}$ understand 'Enough, I don't want to see your face, understood?'

25) Sebab tu lah, aku malas nak kuar. because DEM PART 1s lazy FUT go.out 'That's exactly why I'm reluctant to go out.'

In examples (26-27), lah is used for the purpose of "friendly insults" or jibes.7

26) Kau ni terer lah!

2s DEM daring PART

'You are absolutely amazing!' 
27) Haha, kau poyo lah ek!

PART 2s terrible PART PART

'Haha, you're so terrible!'

In imperative constructions, lah can likewise be used in seemingly contradictory ways; either to soften or to harden what is being said. In the former capacity, it often occurs in pleas, polite request or friendly encouragements (28-30). It is optionally lengthened and typically pronounced in a soft voice.

28) Jangan lah marah, aku main-main ja.

don't PART angry 1s RDP-play PART

'Please don't be angry, I was just joking around.'

29) Tolong lah, aku tak reti camna nak eksplen. help PART 1s not know how FUT explain

'Could you help me, I don't know how to explain it.'

30) Korang duduk lah kat sini dulu.

$2 \mathrm{p}$ sit PART PREP here first

'Why don't you take a seat over here first.'

In other contexts, however, lah emphasizes irritation or disapproval towards the imperative statement it follows (31-33). In this case it is often pronounced in a loud voice.

31) Kalau you tak suka, keluar lah, watpa tunggu lagi? if $2 \mathrm{~s}$ not like go.out PART for.what wait more 'If you don't like it, go away, what are you waiting for?'

32) Belah lah you!

shatter PART 2s

'Drop dead!'

33) Wateber lah, aku tak kisah lah. whatever PART 1s not story PART 'Whatever, I don't care.'

In interrogative statements, lah is optional and emphasizes the question word (34-36). 
34) Sapa lah tak nak aiskrim kan? who PART not want ice.cream PART

'Who wouldn't want ice cream, right?'

35) Apsal lah pelik sangat perangai dia ni. why PART strange very behaviour 3s DEM 'Why is his behaviour so strange?'

36) Sampai bila lah nak jadi macam ni? until when PART FUT become like DEM 'How long will things be like this?'

Lah can also occur as an independent intonational unit. In this case it functions as an interjection drawing the listener's attention to the utterance it precedes (37-38).

37) Lah, kau nak gak ka?

PART 2s want PART PART

'So, you also want some?'

38) Lah, aku cuma nak amik gambar aja.

PART 1s only want take picture PART

'Hey, I only wanted to take a picture.'

\section{4. $k a$}

The particle $\mathrm{ka} / \mathrm{kr} /$ - also written as ke or ker - turns declarative utterances into questions aimed to solicit a yes-or-no response (39-40). ${ }^{8}$ It can also form negative yes-or-no questions (41-42).

39) Saya nampak hodoh $k a$ bila pakai spek? 1s look ugly PART when wear glasses 'Do I look ugly with glasses on?'

40) Gemuk ka aku?

fat PART 1s

'Am I fat?'

41) Belum tidur ka? Ingat kat aku ka? not.yet sleep PART think PREP 1s PART 'Aren't you sleeping yet? Thinking about me?' 
42) Takda orang lain ka?

not.have people other PART

'Is there no one else?'

$\mathrm{Ka}$ can also indicate that multiple possibilities are equally acceptable to the speaker (43-45). ${ }^{9}$ In this construction, it can often be rendered into English as or.

43) Cantik $k a$ tak $k a$ pakai tudung $k a$ tak

pretty PART not PART wear veil PART not

ka sama ja.

PART same PART

'[Whether she's] pretty or not, wearing a veil or not, it's all the same.'

44) Aku suka menda masam, tom yam ka,

1s like thing sour tom.yam PART

mempelam $k a$.

mango PART

'I like sour food, like tom yam or mangos.'

45) Aku tak tau maklumat ni betul ka tak.

1s not know information DEM correct PART not

'I don't know whether this information is true or not.'

The particle $k a$ cannot occur in imperative constructions, nor as an interjection.

\section{5. kan}

The addressee-related particle kan appears to be etymologically derived from bukan 'not'. It is extensively used in Malay and serves to establish common ground and build solidarity between speakers, ${ }^{10}$ somewhat like $y^{\prime}$ know in English. As a marker of shared knowledge, it can be placed before (46-47) or after (48-49) the utterance it modifies.

46) Kan kita pegi tengok sama-sama taim tu.

PART 3p.inc go see together time DEM

'After all, we had seen it together back then.'

47) Kan aku dah cakap be-ratus-ratus kali.

PART 1s PART say QNT-RDP-hunderd time

'I've already said it hundreds of times.'

9 See also kek in Jakartan Indonesian, which functions similarly (Sneddon 2006: 122).

10 This particle has been relatively well described across Malay varieties (Koh 1990: 83-84; Van Minde 1997: 97; Wouk 1998; Stoel 2005: 79-80; Sneddon 2006: 121-122; Sari 2008: 135-138). 
48) Sikit ja kan.

a.bit PART PART

'It's only a bit [as you know].'

49) Nak tidur dulu lah tu kan.

want sleep first PART PART PART

'I'd like to have a rest first [as you can imagine].'

In utterance-final position, kan furthermore serves to request agreement or verification from the listener (50-52). As such it often functions as a question tag, which generally has a rising intonation and can be lengthened. This usage chiefly serves to reduce the distance between the speakers and is not always aimed to solicit a direct answer. Some speakers associate it with feminine speech. ${ }^{11}$

50) Takpa lah, nak buat camna kan. nothing PART FUT do how PART

'No problem, nothing we can do about it.'

51) Tak kisah la tu kan?

no story PART PART PART

'It's no big deal, right?'

52) Ya kan aja lah.

yes PART PART PART

'Well, okay then.'

In certain contexts, $k a n$ is also used to express insensitive comments. Here, it implies common knowledge between the speakers yet does not function as a solidarity marker (53-54).

53) Nak sangat kan ganggu aku!

want very PART disturb 1s

'You really like to disturb me, don't you!?'

54) Kau jantan kan...

2s man PART

'You're supposed to be a man ...'

The particle can occur as a separate intonational unit ('isn't it?'), but not in imperative constructions.

11 This is different from Indonesian, in which the UFP kan does not exhibit clearly gendered patterns of usage (Wouk 1999). 


\section{6. ya}

The affirmative particle $y a / j \gamma /$ 'yes' - also written as ye, yer or yek - can be used as a question tag. As such, it can make a declarative statement into a question or soften an imperative, requesting in both cases the approval or affirmation of the listener. ${ }^{12}$ As a question tag modifying a declarative statement, ya chiefly serves to confirm the speaker's suspicion (55-57).

55) Mak dah keluar ya?

mother PART go.out PART

'Mom has already gone out, hasn't she?'

56) Korang nak tau sangat ya?

$2 p$ want know very PART

'You guys really want to know, don't you?'

57) Model lain dah takda ya?

model other PART have.not PART

'You're out of other models, aren't you?'

$Y a$ is also used as a solidarity marker to form polite questions out of declarative statements. As such, it serves to reduce the distance between speakers and solicit an affirmative response (58-60).

58) Aku tidur dulu ya.

1s sleep first PART

'I'll have some rest now, okay?'

59) Saya datang nak amik gambar ya.

1s come FUT take picture PART

'I came to take a picture, okay?'

60) Kita duduk kat sini ya.

$1 \mathrm{p}$ sit PREP here PART

'We'll sit here, okay?'

The particle can also be used as a low-confidence marker, conveying that the speaker requests the listener's clarification of an insufficiently understood proposition (61-62). In this construction, ya follows the question word. 
61) Apsal ya ramai sangat hari ni...

Why PART crowded very day DEM

'Why are there so many people today ...'

62) Macam mana ya cara nak tambah tinggi?

like what PART way FUT add tall

'What should I do to get taller?'

In imperative constructions, ya softens a directive or request into a pseudoquestion (63-65).

63) Kirim salam kat adik ya.

send regards PREP younger.sibling PART

'Will you say hi to your younger brother?'

64) Lain kali jangan buat lagi ya.

other time don't do again PART

'You won't do it anymore, okay?'

65) Korang kena turun kat sini ya.

$2 \mathrm{p}$ get alight PREP here PART

'This is where you guys should get off.'

Phrase-initially, ya can only be used in its propositional function (66-67).

66) Ya ja lah!

yes PART PART

'Of course!'

67) O ya ka, baru tau.

PART yes PART just.now know

'Really? I never knew.'

\section{UTTERANCE-FINAL PRAGMATICALITY}

This section contains an overview of 17 additional particles used in KVM. As will be shown, their pragmaticality and grammaticality depend on their syntactic position. As will be demonstrated, these particles tend to have relatively more propositional functions in utterance-initial position and more discourse functions in utterance-final position. 


\section{1. dah}

The particle dah is etymologically derived from sudah 'already, finished'. In colloquial Malay, its semantic properties are determined by its syntactic position. Dah forms a perfect tense phrase in pre-verbal position $(d a h+\mathrm{V}=$ 'have+V.PF'), whereas it occupies a syntactic position above the tense phrase post-verbally and sentence-finally (Soh 2011). In the latter case, dah is typically translated into English as already. As observed by Soh (2011), pre-verbal dah can optionally be followed by another dah, while this is not possible for postverbal dah. The following KVM examples corroborate these findings (68-69).

68) Aku dah makan dah kat rumah tadi.

1s PART eat PART PREP house just.now

'I've eaten at home just now.'

69) You siap dah homwok?

2s finished PART homework

'Have you already finished homework?'

Dah can also occur as an interjection, implying that the speaker has had enough of something (70-71).

70) Dah lah tu!

PART PART PART

'Knock it off!'

71) Dah, takyah cita banyak!

PART no.need tell much

'Enough, no need to talk much!'

Sentence-finally, dah conveys a range of pragmatic functions. It often follows utterances or directives that the speaker assumes the listener may find unpleasant. Hence, it also has undergone desemantization ("bleaching") from 'already' to the more abstract meaning of 'accept it already!'. In declarative statements it urges the listener to believe something (72-73), and in imperative statements to do or refrain from doing something (74-75).$^{13}$ In the latter context, it resembles the pragmatic use of already in English ('Stop it already!').

72) I takda masa dah nak pegi pawagam

1s have.not time PART FUT go cinema

'I have no time to go to the cinema.'

13 In this regard it resembles deh in Jakartan Indonesian (Sneddon 2006: 118). 
73) Kalau dia tak nak, takyah paksa dah.

if $3 \mathrm{~s}$ not want no.need force PART

'If he doesn't want it, you don't need to force him.'

74) Sebat ja dah mamat tu!

Hit PART PART guy DEM

'Just hit that guy already!'

75) Jangan nak jadi pompuan dah.

don't want become woman PART

'Stop trying to be a woman.'

2. gak

The additive particle $g a k$ - as well as its full form jugak - indicates similarity with something discussed previously. It follows the proposition it is associated with and can usually be translated into English as also, too, or as well (76-77).

76) Kau nak pegi gak ka?

2s want go PART PART

'Do you want to go as well?'

77) Aku ingin gak belanja ngan korang.

1s wish PART shopping with $2 \mathrm{p}$

'I would like to go shopping with you guys too.'

Gak also expresses that the adverbial phrase it follows possesses more of a certain quality than initially expected (78-79).

78) Cun gak lah dia tu. pretty PART PART 3s PART

'She's actually quite pretty.'

79) Boleh tahan gak dia main bola. can stand PART 3s play ball

'His soccer skills are not too bad.'

3. $j a$

The particle ja - also written as je and jer - is etymologically derived from sahaja and displays the intermediate forms saja and aja. It contains a semantic component of 'nothing else' and is typically translated into English as just or only. Ja and its equivalents saja and aja typically mitigate the proposition 
they follow $(80-81) \cdot{ }^{14}$

80) Cakap macam wat tak tau ja! talk like do not know PART 'Just talk about it as if you don't know anything.'

81) Aku lambat sikit ja sampai. 1s late a.little PART arrive 'I'll arrive a tiny bit late.'

In other contexts, however, $j a$ functions as an emphatic marker expressing irritation (82-83). ${ }^{15}$ In such cases it is typically pronounced in a relatively loud voice and high-falling pitch.

82) Sakit kepala ja nak pikir.

hurt head PART FUT think

'I just get a headache thinking about it.'

83) Jangan duk komplen makan tak best ja. don't PROG complain eat not good PART 'Stop complaining that the food isn't good enough.'

Ja can also occur in a partly reduplicated construction (Koh 1990: 214), following its full form sahaja. In this case, ja emphasizes the semantic component of 'nothing else' (84).

84) Kalau nak buang sampah dalam bilik sahaja ja. if want throw rubbish inside room PART PART

'If you want to throw away rubbish, do so in your room only.'

4. jap

The particle jap, as well as its fuller forms kejap and sekejap 'one moment', conveys that the phrase it modifies is assumed to be of short duration. It is typically used pre-verbally (85-86).

85) Aircond jap ada jap takda.

AC PART have PART have.not

'The AC is turning on and off.'

15 Note that English just also exhibits this function (Aijmer 2000: 171-172). 
86) Jap lagi aku nak apdet dah.

PART more 1s FUT update PART

'I will update it in a bit.'

In post-verbal position, jap has a mitigating effect; the speaker expresses that a possible inconvenience experienced by the listener will soon be over (87).

87) Tolong aku ni masak jap.

help 1s PART cook PART

'Will you help me a sec with the cooking?'

5. jom

The exhortative particle jom urges the listener to do something with the speaker. ${ }^{16}$ It can be placed before the utterance it modifies (88), after it (89), or simultaneously before and after (90).

88) Jom kongsi pengalaman.

PART share experience

'Let share our experiences.'

89) Bro, duduk sini jom!

bro sit here PART

'Let's sit here, bro!'

90) Jom pegi KLCC jom.

PART go KLCC PART

'Let's go to KLCC.'

Utterance-initially, jom is optionally reduplicated (91).

91) Jom-jom, kita masuk keja awal sikit! RDP-PART 1p enter work early a.bit

'Let's go, we'll start working a bit early!'

6. kot

The UFP kot, also written as kut, marks a low degree of confidence in what is being said. ${ }^{17}$ The particle is derived through grammaticalization from the adjective takut 'afraid' and has undergone semantic bleaching to 'one might fear that ...' As an UFP, it expresses uncertainty, doubt, or the fear of negative

16 As such, it is semantically similar to yuk in Jakartan Indonesian (Sneddon 2006: 130), ayo in Indonesian, and ayuh in formal Malay.

17 See Koh (1990: 78) for more examples. 
consequences of the proposition it precedes (92-93) or follows (94-95).

92) Kot kitorang kena denda.

PART 1p.inc get fine

'We might get fined.'

93) Kot jumpa jodoh kat sana.

PART meet match PREP there

'Perhaps you'll meet Mr. Right over there.'

94) Takda kot yang nak beli.

have.not PART REL FUT buy

'What if nobody buys it ...'

95) Mahal sangat lah tu kot.

Expensive very PART PART PART

'That could be very expensive.'

For longer utterances, the particle is often reduplicated and placed utteranceinitially (96-97).

96) Kot-kot boleh bantu korang dapat keja tu.

RDP-PART can help $2 \mathrm{p}$ get work DEM

'She might be able to help you guys finding jobs.'

97) Mana lah tau kot-kot ada orang lain

which PART know RDP-PART have person other

nak cari.

FUT search

'Who knows other people might search for it.'

Kot is rarely used in interrogative constructions, with the exception of rhetorical questions (98-99).

98) Tak reti main bola kot?

not know play ball PART

'Don't you know how to play football?'

99) Takkan pondan kot?

won't gay PART

'You're not gay, are you?'

The particle kot cannot occur in imperative constructions or as an interjection. 


\section{7. lak}

The additive particle lak, as well as its full form pulak, indicates similarity with something discussed previously. Unlike (ju)gak mentioned above, the usage of (pu)lak can convey that the relation between the two events is perceived to be unexpected or infelicitous by the speaker (100-101).

100) Dah langgar lari pulak tu.

PART collide run PART PART

'He crashed his car but still drove away.'

101) Sekarang ni dah musim durian, takkan now DEM PART season durian won't

tak makan lak!

not eat PART

'It's durian season; no way you won't be eating them too!'

Reflecting the same semantic core, lak can also be used pragmatically to express unexpected surprise (102-103).

102) Lupa lak mana dia.

forget PART where 3s

'I totally forgot where she was.'

103) Awak lak wat apa kat sini?

2s PART do what PREP here

'What exactly are you doing here?'

\section{8. meh}

The particle meh has an exhortative function, like jom discussed previously. It conveys that the listener is expected to physically move towards the speaker, corresponding to mari in formal Malay and Indonesian. Like jom, meh can occur pre-verbally (104), post-verbally (105), or both simultaneously (106).

104) Meh akak tolong.

PART older.sister help

'Please come help me, sis.'

105) Jumpa kat Shah Alam meh.

Meet PREP Shah.Alam come

'Come meet us at Shah Alam.' 
106) Meh sambung keja meh.

PART continue work PART

'Let's go back to work.'

9. nah

The particle nah facilitates turn-taking and can also be used to retain the listener's attention. It typically precedes the utterance it modifies (107-108). ${ }^{18}$

107) Nah, ni gambar aku pakai baju kurung.

All right, this picture $1 \mathrm{~s}$ wear dress enclosed.

'All right, this is a picture of me wearing a traditional Malay dress.'

108) Nah kau, dah kawin dan ada anak...

PART 2s PART marry and have kid

'Look at you, all married and with children ...'

Nah can also occur sentence-finally, expressing that speaker has nothing further to say and the listener is expected to do something (109-110).

109) You nak keluar, nah!

2s want go.outside there

'If you want to go outside, please do!'

110) Boleh lah promot kat keng-kawan nah. can PART promote PREP RDP-friend PART

'You're welcome to promote it among your friends.'

10. nak

The frequently used particle nak appears to be etymologically derived from the verb hendak' want'. Next to this literal meaning, it also functions as a temporal verbal auxiliary denoting imminent future (Koh 1990: 209). Sentence-finally, however, nak turns declarative statements into questions, inquiring whether the listener wants to do something together with the speaker (111-112).

111) Kita gi jen-jalan nak?

1p go RDP-walk PART

'We're going for a walk, shall we?'

18 Nah can be used more specifically to express that the listener is about to receive something from the speaker (Koh 1990: 85). As in English, this could also be in the context of a fight (take this!). 
112) Esok ja kita kuar nak?

Tomorrow PART 1p.inc go.out want

'We'll just go out tomorrow, shall we?'

11. $n i$

The main function of $n i$, as well as its full form $i n i$, is a demonstrative pronoun marking proximity to the speaker. It typically refers to objects that are proximate in terms of location ('here') or time ('now'). As such, its range of functions is much broader than English this, with which it is typically translated. In reduplicated form, $n i$ and its distal counterpart $t u$ are frequently used in vivid demonstrations. ${ }^{19}$ As an UFP, ni tends to be used in combination with first person pronouns, typically to convey irritation, disagreement, defiance, and related emotions (Shoho 2006). ${ }^{20}$ The following KVM examples illustrate this usage (113-115).

113) Camna boleh jadi camni ni?

how can become like.this PART

'How could it turn out like this?'

114) Makan se-biji mana cukup ni!

eat one-piece which enough PART

'Eating only one won't be enough!'

115) Kau ni apsal muka macam nak cari gaduh!

2s PART why face like want search fight

'Why does your face look like you're up for a fight!?'

Phrase-initially, ni is always used referentially (116-117).

116) Ni mamat yang masalah tak sudah-sudah.

DEM guy REL problem not RDP-finished

'This is the guy who keeps getting into trouble.'

117) Ni ja lah cerita-ku.

DEM PART PART story-1s

'This is all I have to say.'

19 See Gil (2005: 47-50) on Riau Malay and Van Engelenhoven (2008: 104) on Southwest Maluku Malay.

20 A similar argument is made by Koh (1990: 188-191). 


\section{2. pun}

The particle pun - also written as pon - is extremely common, versatile, and often poorly explained in Malay grammars. ${ }^{21}$ In KVM, pun primarily functions as an additive particle, exhibiting in some contexts an inclusive meaning - that is, "an unordered set of contextually relevant values" (König 1991: 60) - and in others a scalar one. These constructions tend to be translated into English with conjunctive adverbs; also or either for inclusive interpretations (118) and even for scalar ones (119).

118) I pun tak pernah tengok filem BudSpencer tu. 1s PART not ever see movie Bud Spencer DEM

'I've never seen that Bud Spencer movie either.'

119) Menda senang pun takleh buat! thing easy PART cannot do

'Even the easy stuff you can't do!'

Utterance-finally, pun can also indicate that the phrase it modifies is surprising or contrary to the speaker's or listener's expectations (120-122). ${ }^{22}$

$\begin{array}{lllllll}\text { 120) Beli tudung mahal takda pun orang cakap cantik. } \\ \text { buy veil } & \text { expensive have.not PART person say pretty }\end{array}$

'I bought an expensive veil but nobody said it was pretty.'

121) Aku mana reti pun main bola?

1s which know PART play ball

'How could I have known how to play football?'

122) Diorang tau pun dari gosip.

$3 p \quad$ know PART from gossip

'They know it only through gossip.'

This "counterintuitive" usage of pun also serves to assert that the speaker is correct and should be believed by the listener, who may hold a different conviction (123-125). ${ }^{23}$

$\begin{array}{llllll}\text { 123) } & \text { Tu } \quad \text { ja lah pun yang kita } & \text { ada. } \\ \text { DEM PART } & \text { PART PART } & \text { REL } & \text { 1p } & \text { have } \\ \text { 'That's really all we have.' } & & & \end{array}$

21 This particle is extensively used in classical Malay (Cumming 1991: 84-154) as well as colloquial Malay, in which it exhibits a wide variety of syntactic functions by itself or in combination with several other particles (Goddard 2001; Chambert-Loir forthcoming).

22 See Goddard (2001: 41-43) for more discussion and examples of this usage.

23 In this regard, it resembles the colloquial Indonesian UFP kok (Sneddon 2006: 122-123). 
124) Dia tak cakap pun kau salah.

3s not say PART 2s wrong

'She never said you're wrong.'

125) Aku tak nak pun pegi sekolah!

1s not want PART go school

'But I don't want to go to school!'

The particle pun cannot form imperative constructions or interjections.

\section{3. punya}

The possessive marker punya 'have' - from classical Malay empu-nya '(is) the owner' - can be used pragmatically as an UFP, indicating that the utterance it follows is absolutely obvious in the eyes of the speaker. This usage of punya also implies that the listener should have known the proposition it follows (126-128). ${ }^{24}$ Punya is sometimes pronounced as / pia/ or / mia/ in KVM, but is rarely spelled as such.

126) Kalau tak paksa, mesti tak datang punya. if not force definitely not come PART

'He'll definitely never show up if you don't force him.'

127) Ini budak macam takda lesen punya...

DEM kid like have.not license PART

'That guy obviously doesn't have a driver's license ...'

128) Memang akak akan ikut punya.

indeed older.sister will join PART

'Of course my older sister will join us.'

When modifying an adverbial phrase, punya occurs utterance-initially and functions as an intensifier of the adjective it modifies (129) ${ }^{25}$

129) Tengok lah punya gemuk tak muat gambar. look PART PART fat not fit picture

'Look how fat they are, they don't even fit in the same picture.'

24 This is discussed in detail by Koh (1990: 78-79), Yap (2007), and Soh (2015).

25 This usage is not restricted to KVM. It has also been described for Ambon Malay (Van Minde 1997: 197), Manado Malay (Stoel 2005: 45-46), West Malaysian Malay (Yap 2007), Sabah Malay (Hoogervorst 2011: 68), and Papua Malay (Kluge 2014: 412), among others. 
In other contexts, punya functions as a possessive marker placed between the possessor and the possessed item (130). The latter can be omitted if clear from the context (131).

130) You punya awek takda ka?
2s POS girlfriend have.not PART
'Your girlfriend wasn't there?'

131) Nah, aku punya kat mana? PART 1s POS PREP where 'So, where is mine?'

Along similar lines, punya can modify adverbial phrases in the head-initial position (132). If clear from the context, the head noun can be omitted (133).

Apa punya kawan lah kau ni!
what POS friend

'What kind of friend are you supposed to be!'

133) Mana nak dapat yang sedap punya kat sini? where FUT get REL tasty POS PREP here 'Where can I get the tastiest ones over here?'

Related to the above usage, punya can also link relative clauses to noun phrases (Koh 1990: 191-198; Yap 2007). This function might reflect influence from conventionalized foreigner talk (bahasa pasar). It has been described in more detail by Pakir (1986: 137-162), Aye (2005: 253-266), and Yap (2007), who demonstrate that such usage of the possessive marker ultimately goes back to Hokkien.

\section{4. tah}

The UFP tah, like kot discussed above, marks a low degree of confidence in what is being said. Etymologically, it appears to be related to standard Malay entah 'who knows; I don't know' and the (infrequently used) interrogative particle -tah. This usage is illustrated in examples (134-135).

134) Tah lah, tu ja kot?

PART PART DEM PART PART

'Dunno, maybe only that one?'

135) Tah ada $k a$ tak orang ingat harijadi aku. PART have PART not person remember birthday 1s 'I'm not sure if there's anybody who has remembered my birthday.' 
Tah can also be used in the context of a rhetorical question, in which case it follows the interrogative segment (136-138).

136) Camna tah boleh lupa nak beli nasi? how PART can forget FUT buy rice 'How could I forget to buy rice?'

137) Apsal tah tetiba ja aku te-rasa rindu why PART suddenly PART 1s STAT-feel longing

kat dia?

PREP 3s

'Why did I suddenly feel a sense of longing for him?'

138) Ada bapa orang tah kat sini

have how.many person PART PREP here

aku pun tak tau lah.

1s PART not know PART

'I have no idea how many people live here.'

In declarative statements, tah conveys the speaker's uncertainty about the proposition it modifies. In this case the particle precedes the interrogative phrase (139-140). Another tah may optionally follow it (141-142).

139) Aku ni tah sejak bila suka makan

1s DEM PART since when like eat

cencaluk.

fermented.shrimps

'I've liked eating fermented shrimps for some time now.'

140) Tah napa tetiba aku nak komen.

PART why suddenly $1 \mathrm{~s}$ want comment

'For some reason I suddenly felt like commenting.'

141) Budak tu dah pegi tah kat mana tah.

kid DEM PART go PART PREP where PART

'That kid has gone to some place.'

142) Dia nak kawin tah ngan siapa tah.

3s FUT marry PART with who PART

'She's going to marry some person.' 
In doubled form, tah can be placed before an utterance to indicate that its propositional value is possible but not certain to the speaker (143-144).

143) Tah-tah ada yang masuk spital ni.

RDP-PART have REL enter hospital PART

'Some people may have ended up in the hospital.'

144) Eh, tah-tah mamat tu lagi kuat dari kau!

PART RDP-PART guy DEM more strong from $2 \mathrm{~s}$

'Hey, that guy might just be stronger than you!'

15. tak

Tak is a commonly used negative particle in KVM, typically translated into English as no or not (145-146).

145) Tak, aku tak nak!

not 1s not want

'No! I don't want to!'

146) Tak lah kot.

not PART PART

'It doesn't seem so.'

It can also function as a question tag, transforming declarative statements into interrogative ones. The questions so formed are meant to be either affirmed or denied, with tak following the element being questioned (147-149). The particle tak does not occur in negative questions, in which case $k a$ must be used. It can also not be used in imperative constructions.

147) Amacam, nampak real tak?

like.what look real PART

'How is it, does it look real?'

148) Cun tak awek ni?

pretty PART girl DEM

'Is this girl pretty or not?'

149) Senang tak nak masuk UKM?

easy PART FUT enter UKM

'Is it easy to enter the National University of Malaysia?'

The post-verbal use of tak in questions often reduces the distance between the speakers and adds a dimension of politeness (150-152). 
150) Agaknya ada tak orang nak komen? likely have PART person FUT comment

'Is it likely that someone will comment?'

151) Boleh tak kau bagi detil sikit pasal menda ni? can PART $2 \mathrm{~s}$ give detail a.bit about thing DEM

'Could you give a bit of detail about the issue?'

152) Masih ingat tak masa kecik-kecik dulu?

still remember PART time RDP-little first

'Do you still remember the time when you were little?'

16. $\mathrm{tau}$

In its original sense, tau means 'to know'. It can also be used as an emotive particle, indicating that the speaker believes the listener should already know what is being said. The particle conveys a sense of irritation that this turns out not to be the case; 'how could you not know this?'. In this usage, tau follows the utterance it modifies (153-155).

153) Jangan se-kali-kali lewat tau!

don't one-RDP-time pass.by PART

'Don't ever show yourself here!'

154) Keja kat sini memang best lah tau.

work PREP here indeed good PART PART

'It's definitely great to work here!'

155) Susah nak dapat kawan macam ini tau.

hard FUT find friend like DEM PART

'How hard it is to find a friend like this ...'

Tau retains its propositional character in all other types of phrases (156-158), where it functions as a verb.

156) Tak cuba tak tau kan.

not try not know PART

'You don't know until you try, right?' 
157) Kita harap lah yang belum tau

$1 \mathrm{p}$ hope PART REL not.yet know

tu dah tau.

DEM PART know

'We hope that those who didn't know it will know by now.'

158) Korang tau tu ek!

$2 \mathrm{p}$ know DEM PART

'You knew that, guys!'

17. $t u$

In its function as a demonstrative, $t u$ - as well as its full form itu - marks distance between the speaker and the referred object in terms of location ('there') or time ('then'). Like ni discussed previously, tu can be used nonreferentially to convey the speaker's irritation and other negative emotions towards the utterance it follows. As such, the UFP $t u$ is less versatile and can occur in fewer contexts than $n i$, as it modifies objects that are distant to the speaker. ${ }^{26}$ Consider the following examples (159-161).

159) Camna tu nak atasi?

how PART FUT handle

'How should we handle it?'

160) Dia tu tak pernah pun datang rumah aku!

3s PART not ever PART come house 1s

'He's never even come to my house!'

161) Tengok lah tu diorang buat apa!

look PART PART $3 p$ do what

'Look what they have done!'

Utterance-initially, tu can only function as a demonstrative (162-163).

162) Tu lah kan, kita dah kena tipu.

DEM PART PART 1p PART get trick

'There you have it, we just got scammed.'

26 This is shown in more detail in Shoho (2006). A similar argument is made by Koh (1990: 188-191). 
163) Tu takleh nak makan!

DEM cannot FUT eat

'That's something you shouldn't eat!'

\section{CONCLUDING REMARKS}

Previous studies on Malay and Malaysian/Singaporean English varieties have treated UFPs, also known under many other names, as a discrete word class. This article has tried to demonstrate on the basis of evidence from Klang Valley Malay that most UFPs - with the exception of $k a$ and kot - exhibit semantically related homophones belonging to other word classes, thus effectively representing a "continuum of pragmaticality" ${ }^{27}$ To understand the broad range of meanings expressed by these particles, it is therefore crucial to take into account their diachronic evolution and associated processes of semantic bleaching. Almost every particle in KVM has become monosyllabic (or has a monosyllabic equivalent) and polysemous, displaying semantic meanings alongside abstract pragmatic meanings. As such, they cannot be understood as belonging to a closed word class. The UFPs outlined in this study display ongoing processes of grammaticalization towards particlehood and pragmaticalization towards discourse functions. ${ }^{28}$ These overlapping properties are provisionally outlined in Table 1.

Several factors need to be taken into account systematically to determine whether - in KVM as well as other languages - a linguistic unit functions as an UFP in a given context. These include the particle's intonation and syllabicity, its syntactic position, the degree of non-pragmatic information it adds to the proposition, and the degree of referentiality in the case of $n i$ and $t u$. A corpus-based approach constitutes a logical next step to develop these insights beyond what this study has been able to cover. Doing so would provide better opportunities to solicit the feedback of native speakers. A corpus of spontaneous language would also ideally contain quantifiable data to detect common patterns of co-occurrence and link frequency of usage to gender, age, and possibly education and ethnicity. As regards the latter, this study has not included UFPs solely in use among Chinese speakers of Malay - such as mah, meh, lor, and liao - but their occurrence is not to be neglected in future research.

\footnotetext{
27 Term taken from Crible (2017: 101). Also see Fischer (2006: 3) on the need to examine homophones and other features to arrive at a fuller understanding of UFPs more generally. 28 See Van Bogaert and Colleman (2013) on the former and Diewald (2011) and Degand and Evers-Vermeul (2015) on the latter.
} 


\begin{tabular}{|c|c|c|c|c|c|c|c|c|c|c|c|c|c|c|c|c|c|c|c|c|c|}
\hline & \multicolumn{2}{|c|}{ syllabicity } & \multicolumn{5}{|c|}{$\begin{array}{l}\text { possible syntactic } \\
\text { position }\end{array}$} & \multicolumn{5}{|c|}{$\begin{array}{l}\text { possible construction (in } \\
\text { utterance-final position) }\end{array}$} & \multicolumn{6}{|c|}{$\begin{array}{l}\text { possible pragmatic usage (in } \\
\text { utterance-final position) }\end{array}$} & \multicolumn{3}{|c|}{$\begin{array}{l}\text { possible } \\
\text { propositional } \\
\text { usage }\end{array}$} \\
\hline & 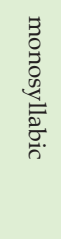 & 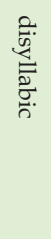 & 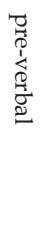 & 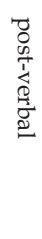 & 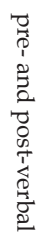 & 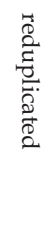 & 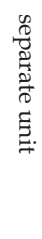 & 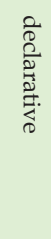 & 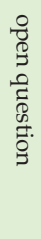 & 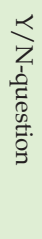 & 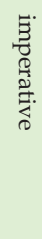 & 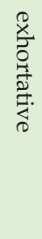 & $\begin{array}{l}\overrightarrow{0} \\
2 \\
2 \\
0 \\
0 \\
0 \\
\overrightarrow{0} \\
\overrightarrow{0} \\
\overrightarrow{0} \\
0 \\
0\end{array}$ & 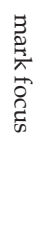 & 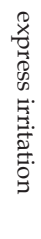 & 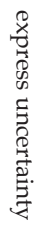 & 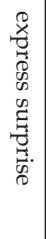 & 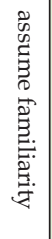 & 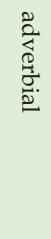 & 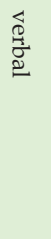 & 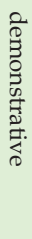 \\
\hline$a h$ & $x$ & & & $x$ & & & $x$ & $x$ & $x$ & & $x$ & & & & $x$ & & & & & & \\
\hline dah & $x$ & & $x$ & $x$ & $x$ & & $x$ & $x$ & & & $x$ & & & & & & & & $x$ & & \\
\hline$e k$ & $x$ & & & $x$ & & & & $x$ & $x$ & & $x$ & & $X$ & & & & & & & & \\
\hline gak & $x$ & $(X)$ & & $x$ & & & & $x$ & & & & & & & & & $x$ & & $x$ & & \\
\hline ja & $x$ & & & $x$ & & $(X)$ & & $x$ & & & & & & & $x$ & & & & & & \\
\hline jap & $x$ & & $x$ & $x$ & & & $x$ & $x$ & & & & & $X$ & & & & & & & & \\
\hline jom & $x$ & & $x$ & $x$ & $x$ & $x$ & $x$ & & & & & $x$ & $X$ & & & & & & & & \\
\hline$k a$ & $x$ & & & $x$ & & & & & & $x$ & & & & & & & & & & & \\
\hline kan & $x$ & & $x$ & $x$ & & & $x$ & & & $x$ & & & $X$ & & & & & $x$ & & & \\
\hline kot & $x$ & & $x$ & $x$ & & $x$ & & $x$ & & & & & & & & $x$ & & & & & \\
\hline lah & $x$ & & & $x$ & & & $x$ & $x$ & & & $x$ & & $X$ & $x$ & $x$ & & & & & & \\
\hline lak & $x$ & $(X)$ & & $x$ & & & & $x$ & & & & & & & $x$ & & $x$ & & $x$ & & \\
\hline meh & $x$ & & $x$ & $x$ & $x$ & & $X$ & & & & & $x$ & $X$ & & & & & & & $(X)$ & \\
\hline nah & $x$ & & $x$ & $x$ & & & $x$ & & & & & $x$ & & & & & & & & & \\
\hline nak & $x$ & & $x$ & $x$ & & & $x$ & & & $x$ & & & & & & & & & & & \\
\hline$n i$ & $x$ & & & $x$ & & & $x$ & $x$ & $x$ & & & & & & $x$ & & & & & & $x$ \\
\hline pun & $x$ & & & $x$ & & & & $x$ & & & & & & & & & $x$ & & $X$ & & \\
\hline punya & $(X)$ & $x$ & $x$ & $x$ & & & $x$ & $x$ & & & & & & & & & & $x$ & & $x$ & \\
\hline tah & $x$ & & $x$ & $x$ & & $x$ & $x$ & $x$ & & & & & & & & $x$ & & & & & \\
\hline tak & $x$ & & $x$ & $x$ & & & $x$ & & & $x$ & & & $x$ & & & & & & & & \\
\hline tau & $x$ & & & $x$ & & & $x$ & $x$ & & & & & & & $x$ & & & $x$ & & $x$ & \\
\hline tu & $x$ & & & $x$ & & & $x$ & $x$ & $x$ & & & & & & $x$ & & & & & & $x$ \\
\hline$y a$ & $x$ & & & $x$ & & & $x$ & & & $x$ & $x$ & & $X$ & & & & & & & & \\
\hline
\end{tabular}

Table 1. Utterance-final particles and their characteristics in Klang Valley Malay. 
GLOSSING CONVENTIONS

Affix boundaries are indicated by a hyphen (-). Multiword glosses are separated by periods (like.this). The following glossing conventions are used:

$\begin{array}{ll}1 & \text { first-person } \\ 2 & \text { second-person } \\ 3 & \text { third-person } \\ \text { DEM } & \text { demonstrative } \\ \text { FUT } & \text { future marker } \\ \text { inc } & \text { plural inclusive } \\ \text { p } & \text { plural } \\ \text { PART } & \text { particle } \\ \text { PF } & \text { perfect } \\ \text { POS } & \text { possessive } \\ \text { PREP } & \text { preposition } \\ \text { PROG } & \text { progressive } \\ \text { QNT } & \text { quantifier } \\ \text { RDP } & \text { reduplication } \\ \text { REL } & \text { relative marker } \\ \text { S } & \text { singular } \\ \text { STAT } & \text { stative } \\ \text { V } & \text { verb }\end{array}$

\section{REFERENCES}

Abraham, Werner (ed.). 1991. Discourse particles; Descriptive and theoretical investigations on the logical, syntactic and pragmatic properties of discourse particles in German. Amsterdam/Philadephia, PA: John Benjamins.

Aijmer, Karin. 2000. English discourse particles: Evidence from a corpus. Amsterdam/Philadelphia, PA: John Benjamins.

Aijmer, Karin and Anne-Marie Simon-Vandenbergen (eds). 2006. Pragmatic markers in contrast. Amsterdam: Elsevier.

Asmah, Haji Omar. 1992. The linguistic scenery in Malaysia. Kuala Lumpur: Dewan Bahasa dan Pustaka.

Asmah, Haji Omar. 2008. Susur galur Bahasa Melayu. Second edition. Kuala Lumpur: Dewan Bahasa dan Pustaka.

Aye, Daw Khin Khin. 2005. Bazaar Malay; History, grammar, and contact. PhD thesis, National University of Singapore.

Bayer, Josef and Volker Struckmeier (eds). 2017. Discourse particles; Formal approaches to their syntax and semantics. Berlin/Boston, MA: De Gruyter.

Blakemore, Diane. 2002. Relevance and linguistic meaning; The semantics and pragmatics of discourse markers. Cambridge: Cambridge University Press. 
Bogaert, Julie van and Timothy Colleman. 2013. “On the grammaticalization of ('t) schijnt 'it seems' as an evidential particle in colloquial Belgian Dutch", Folia Linguistica 47(2): 481-520.

Chambert-Loir. Forthcoming. "Pun". [Unpublished paper.]

Collins, James T. 1989. "Malay dialect research in Malysia; The issue of perspective", Bijdragen tot de Taal-, Land-en Volkenkunde 145 (2/3): 235-264.

Collins, James T. and Naseh Hassan. 1986. “Dialek Melayu Selangor: Tinjauan di Jugra", Jurnal Persatuan Linguistik 2: 74-94.

Coope, A.E. 1953. A guide to Malay conversation. Third edition. Singapore: Kelly \& Walsh.

Crible, Ludivine. 2017. “Towards an operational category of discourse markers; A definition and its model", in: Chiara Fedriani and Andrea Sansò (eds), Pragmatic markers, discourse markers and modal particles; New perspectives, pp. 99-124. Amsterdam/Philadelphia, PA: John Benjamins.

Cumming, Susanna. 1991. Functional change; The case of Malay constituent order. Berlin/New York, NY: Mouton de Gruyter.

Degand, Liesbeth and Jacqueline Evers-Vermeul. 2015. "Grammaticalization or pragmaticalization of discourse markers? More than a terminological issue", Journal of Historical Pragmatics 16(1): 59-85.

Engelenhoven, Aone van. 2008. "Ini apel ni nya 'This here apple now'; Deictics in the Malay speech of Southwest Malukan migrants in the Netherlands", Wacana, Journal of the Humanities of Indonesia 10(1): 90-116.

Diewald, Gabriele. 2011. "Pragmaticalization (defined) as grammaticalization of discourse functions", Linguistics 49(2): 365-390.

Fedriani, Chiara and Andrea Sansò. 2017. "Pragmatic markers, discourse markers and modal particles; What do we know and where do we go from here?", in: Chiara Fedriani and Andrea Sansò (eds), Pragmatic markers, discourse markers and modal particles; New perspectives, pp.1-33. Amsterdam/ Philadelphia: John Benjamins.

Fischer, Kerstin. 2006. "Towards an understanding of the spectrum of approaches to discourse particles; Introduction to the volume", in: Kerstin Fischer (ed.), Approaches to discourse particles, pp. 1-20. Amsterdam: Elsevier. Foolen, Ad. 1996. "Pragmatic particles", in: Jef Verschueren, Jan-Ola Östman, Jan Blommaert, and Chris Bulcaen (eds), Handbook of Pragmatics 1996, pp. 1-24. Amsterdam/Philadelphia, PA: John Benjamins.

Fraser, Bruce. 1990. "An approach to discourse markers", Journal of Pragmatics 14: 383-395.

Gil, David. 2005. "From repetition to reduplication in Riau Indonesian", in: Bernhard Hurch (ed.), Studies on reduplication, pp. 31-64. Berlin/New York, NY: Mouton de Gruyter.

Goddard, Cliff. 1994. “The meaning of lah; Understanding 'emphasis' in Malay (Bahasa Melayu)", Oceanic Linguistics 33(1): 145-165.

Goddard, Cliff. 2001. "The polyfunctional Malay focus particle pun", Multilingua 20(1): 27-59.

Gupta, Anthea Fraser. 1992. “The pragmatic particles of Singapore colloquial English", Journal of Pragmatics 18: 31-57. 
Gupta, Anthea Fraser. 2006. “Epistemic modalities and the discourse particles of Singapore", in: Kerstin Fischer (ed.), Approaches to discourse particles, pp. 243-263. Amsterdam: Elsevier.

Hoogervorst, Tom G. 2011. "Some introductory notes on the development and characteristics of Sabah Malay", Wacana, Journal of the Humanities of Indonesia 13(1): 50-77.

Hoogervorst, Tom G. 2015. "Malay youth language in West Malaysia", Nusa 58: 25-49.

Hussein, Ismail. 1973. "Malay dialects in the Malay Peninsula", Nusantara 3: 69-79.

Ikranagara, Kay. 1975. “Lexical particles in Betawi”, Linguistics 13(165): 93-108. Jucker, Andreas H. and Yael Ziv (eds). 1998. Discourse markers; Description and theory. Amsterdam/Philadelphia, PA: Benjamins.

Koh, Ann Sweesun. 1990. Topics in colloquial Malay. PhD thesis, University of Melbourne.

König, Ekkehard. 1991. The meaning of focus particles; A comparative perspective. London/New York, NY: Routledge.

Kluge, Angela. 2014. A grammar of Papuan Malay. Utrecht: LOT.

Lehmann, Christian. 1985. "Grammaticalization; Synchronic variation and diachronic change", Lingua e Stile 20: 303-318.

Li Chia Tay, Mei Yuit Chan, Ngee Thai Yap, and Bee Eng Wong. 2016. "Discourse particles in Malaysian English; What do they mean?", Bijdragen tot de Taal-, Land-en Volkenkunde 172(4): 479-509.

Lin, Chin-Hui. 2014. Utterance-final particles in Taiwan Mandarin; Contact, context and core functions. Utrecht: LOT.

Maschler, Yael and Deborah Schiffrin. 2015. “Discourse markers; Language, meaning, and context", in: Deborah Tannen, Heidi E. Hamilton, and Deborah Schiffrin (eds), The handbook of discourse analysis. Volume 1, pp. 189-221. Second edition. Malden, Massachusetts, MA/Oxford: Blackwell.

Minde, Don van. 1997. Malayu Ambong: Phonology, morphology, syntax. Leiden: CNWS.

Minde, Don van. 2008. "Review of Ruben Stoel (2005), Focus in Manado Malay; Grammar, particles, and intonation", Bijdragen tot de Taal-, Land-en Volkenkunde 162(4): 555-557.

Nomoto, Hiroki. 2006a. "The multi-purpose preposition kat in colloquial Malay", 言語情報学研究報告䇻 11: 69-94.

Nomoto, Hiroki. 2006b. “Voice in colloquial Malay relatives"，言語情報学研 究報告笵 12: 79-116.

Nomoto, Hiroki and Kartini Abd. Wahab. 2012. "Kena adversative passives in Malay, funny control, and covert voice alternation", Oceanic Linguistics 51(2): 360-386.

Östman, J.O. 1981. 'You know': A discourse functional approach. Amsterdam/ Philadelphia, PA: John Benjamin.

Platt, John T. and Mian Lian Ho. 1989. “Discourse particles in Singaporean English; Substratum influences and universals", World Englishes 8(2): 215-221. 
Sari, Faizah. 2008. "Teaching pragmatic particles in the LCTL classroom", Journal of the National Council of Less Commonly Taught Languages 5: 129-159.

Sari, Faizah. 2011. "A cross-linguistic dimension of the pragmatic particle $y a$ ", Linguistik Indonesia 29(1): 53-68.

Schiffrin, Deborah. 1987. Discourse markers. Cambridge: Cambridge University Press.

Schiffrin, Deborah. 2003. “Discourse markers: Language, meaning, and context", in: Deborah Schiffrin, Deborah Tannen, and Heidi E. Hamilton (eds), The handbook of discourse analysis, pp. 54-75. Second edition. Malden, MA: Blackwell.

Shoho, Isamu. 2006. "Nonreferential use of demonstrative pronouns in colloquial Malay", in: Susumu Zaima, Yuji Kawaguchi, and Toshihiro Takagaki (eds), Spoken language corpus and linguistic informatics, pp. 287-301. Amsterdam/Philadelphia, PA: John Benjamins.

Shoho, Isamu. 2013. "Unsettled problems of Malay demonstrative pronouns", in: Hiroki Nomoto, Zaharani Ahmad, and Anwar Ridhwan (eds), Isamu Shoho: Tinta kenangan; Kumpulan esei bahasa dan linguistik, pp. 145-189. Kuala Lumpur: Dewan Bahasa dan Pustaka.

Sneddon, James Neil. 2006. Colloquial Jakartan Indonesian. Canberra: Pacific Linguistics.

Soh, Hooi Ling. 2011. "The syntax of dah in colloquial Malay". [Paper presented at the 15th International Symposium on Malay/Indonesian Linguistics (ISMIL), Universitas Islam Negeri Malang, Malang, Indonesia, 23-24 June 2011.]

Soh, Hooi Ling. 2015. 'Evidentiality and modality: The case of sentence final punya in colloquial Malay.' Paper presented at the 22nd meeting of the Austronesian Formal Linguistics Association (AFLA), McGill University, Montreal, Canada, 21-24 May 2015.

Stoel, Ruben. 2005. Focus in Manado Malay; Grammar, particles, and intonation. Leiden: CNWS Publications.

Traugott, Elizabeth Closs.1988. "Pragmatic strengthening and grammaticalization", Berkeley Linguistic Society 14: 406-416.

Wouk, Fay. 1998. “Solidarity in Indonesian conversation; The discourse marker kan", Multilingua 17: 381-408.

Wouk, Fay. 1999. "Gender and the use of pragmatic particles in Indonesian", Journal of Sociolinguistics 3: 194-200.

Wouk, Fay. 2001. "Solidarity in Indonesian conversation; The discourse marker ya", Journal of Pragmatics 33: 171-191.

Yap, Foong Ha. 2007. “On native and contact-induced grammaticalization; The case of Malay empunya". [Unpublished paper.]

Zorc, David Paul. 1977. The Bisayan dialects of the Philippines; Subgrouping and reconstruction. Canberra: Pacific Linguistics. 